\title{
ResearchArticle
}

\section{Effect of growth regulators and fruit retention on fruit set, seed yield and quality of tomato parental lines}

\author{
SANJEEVKUMAR, B.S. VYAKARNAHAL, V.K. DESHPANDE AND PRIYA KIVADASANNAVAR
}

\begin{abstract}
SUMMARY
Parental seed production in tomato, number of fruits retained on seed parent and pollen parent will decide not only seed yield but also seed quality. Application of growth regulators like $\mathrm{GA}_{3}$, NAA are known to modify plant morphophysiological characters and help in getting higher seed yield coupled with better quality traits. Among growth regulators $\mathrm{GA}_{3} 100 \mathrm{ppm}$ recorded significantly higher fruit yield/plant $(1206.01 \mathrm{~g})$, seed yield/plant $(8.12 \mathrm{~g})$ and germination $(90.92 \%)$ and vigour index (1424) over control (1101.69g, 7.36g, 87.60\% and 1301, respectively) Retention of all fruits recorded higher fruit yield $(1824.79 \mathrm{~g})$ and seed yield/plant $(11.38 \mathrm{~g})$ compared to 10,15 and 20 fruits. Germination $(91.51 \%)$ and vigour index (1460) were significantly higher in 10 fruits per plant compared all fruits treatments. Among the treatment combinations, $\mathrm{GA}_{3} 100 \mathrm{ppm}$ with retention of all fruits recorded significantly higher fruit yield/plant (1898.10g), seed yield/plant (11.95g). vigour index (1501) was significantly higher in $\mathrm{GA}_{3} 100 \mathrm{ppm}$ with 10 fruits compared to other treatment combinations.
\end{abstract}

Key Words : Growth regulators, Fruit retention, Tomato, Parental lines

How to cite this article : Sanjeevkumar, Vyakarnahal, B.S., Deshpande, V.K. and Kivadasannavar, Priya (2016). Effect of growth regulators and fruit retention on fruit set, seed yield and quality of tomato parental lines. Internat. J. Plant Sci., 11 (2): 322-330, DOI: 10.15740/HAS/IJPS/11.2/322-330.

Article chronicle : Received : 28.12.2015; Revised : 23.05.2016; Accepted : 23.06.2016

\section{MEMBERS OF THE RESEARCH FORUM}

Author to be contacted :

B. S. VYAKARANAHAL, Department of Seed Science and Technology, College of Agriculture, University of Agricultural Sciences, DHARWAD (KARNATAKA) INDIA

Email: basannasv@gmail.com; basannasv@rediffmail.com

Address of the Co-authors:

SANJEEVKUMAR, V.K. DESHPANDE AND PRIYA

KIVADASANNAVAR, Department of Seed Science and Technology,

University of Agricultural Sciences, DHARWAD (KARNATAKA) INDIA

Email: Priya.bk@ rediffmail.com 